\title{
Evaluating the Significance of Wetland Restoration Scenarios on Phosphorus Removal
}

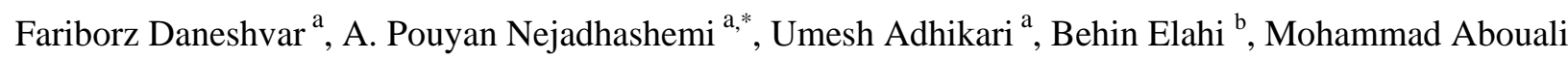

${ }^{\text {a }}$, Matthew R. Herman ${ }^{\text {a }}$, Edwin Martinez-Martinez ${ }^{\text {c }}$, Timothy J. Calappi ${ }^{\text {d }}$, Bridget G. Rohn ${ }^{\text {d }}$

${ }^{a}$ Department of Biosystems and Agricultural Engineering, Michigan State University, 524 S. Shaw Lane, Room 216, East Lansing, MI 48824 USA

${ }^{\mathrm{b}}$ Department of Supply Chain Management, Michigan State University, 632 Bogue St., Room N370, East Lansing, MI 48824

USA

${ }^{\mathrm{c}}$ U.S. Department of Agriculture, Natural Resources Conservation Service Agency, 271 W. McCoy Rd., Gaylord, MI 49735

USA

${ }^{\mathrm{d}}$ U.S. Army Corps of Engineers, 477 Michigan Ave., Detroit, MI 48226 USA

* Corresponding author: Tel.: +1 (517) 432-7653 Fax: +1 (517) 432-2892. Email address: pouyan@ msu.edu (A. Pouyan Nejadhashemi)

\begin{abstract}
Freshwater resources are vital for human and natural systems. However, anthropogenic activities, such as agricultural practices, have led to the degradation of the quality of these limited resources through pollutant loading. Agricultural Best Management Practices (BMPs), such as wetlands, are recommended as a valuable solution for pollutant removal. However, evaluation of their long-term impacts is difficult and requires modeling since performing in-situ monitoring is expensive and not feasible at the watershed scale. In this study, the impact of natural wetland implementation on total phosphorus reduction was evaluated both at the subwatershed and
\end{abstract}


watershed levels. The study area is the Saginaw River Watershed, which is largest watershed in Michigan. The phosphorus reduction performances of four different wetland sizes $(2,4,6$, and 8 hectares) were evaluated within this study area by implementing one wetland at a time in areas identified to have the highest potential for wetland restoration. The subwatershed level phosphorus loads were obtained from a calibrated Soil and Water Assessment Tool (SWAT) model. These loads were then incorporated into a wetland model (System for Urban Stormwater Treatment and Analysis IntegratioN-SUSTAIN) to evaluate phosphorus reduction at the subwatershed level and then the SWAT model was again used to route phosphorus transport to the watershed outlet. Statistical analyses were performed to evaluate the spatial impact of wetland size and placement on phosphorus reduction. Overall, the performance of 2 ha wetlands in total phosphorus reduction was significantly lower than the larger sizes at both the subwatershed and watershed levels. Regarding wetland implementation sites, wetlands located in headwaters and downstream had significantly higher phosphorus reduction than the ones located in the middle of the watershed. More specifically, wetlands implemented at distances ranging from $200-250 \mathrm{~km}$ and $50-100 \mathrm{~km}$ from the outlet had the highest impact on phosphorus reduction at the subwatershed and watershed levels, respectively. A multi criteria decision making (MCDM) method named VIKOR was successfully executed to identify the most suitable wetland size and location for each subwatershed considering the phosphorus reduction and economic cost associated with wetland implementation. The methods introduced in this study can be easily applied to other watersheds for selection and placement of wetlands while considering environmental benefits and economic costs.

Keywords: SWAT; SUSTAIN; VIKOR; Wetland; Phosphorus; Saginaw 


\section{Introduction}

Phosphorus originating from the agricultural sources has long been identified as the major cause of water quality problems in the United States (Parry, 1998; Gentry et al., 2007). A decadal (1993-2003) assessment of the streams in the U.S. showed that streams draining from agricultural and urban areas have the highest concentration of phosphorus with an increasing trend over the years (Dubrovsky et al., 2010). Lake eutrophication and cyanobacteria blooms caused by excess phosphorus can not only restrict water use, but also pose health risks to animals and humans (Sharpley et al., 2003). Recent large-scale algal blooms in Lake Erie were found to be driven by increased phosphorus loadings from agricultural practices (Michalak et al., 2013). Hence, it is imperative to control phosphorus loads to waterbodies in order to reduce lake eutrophication and algal blooms (Schindler et al., 2008).

Wetlands combine characteristics of both terrestrial systems and aquatic systems and are wet at least part of the year (Kadlec and Wallace, 2008). Apart from runoff attenuation, wetlands are also effective in removing sediments and nutrients originating from various sources (Woltemade, 2000; Jordan et al., 2003; Kadlec, 2005). Major wetland processes that contribute to phosphorus removal include uptake by microbes and vegetation, sorption and burial in soil and sediments (peat accretion) and precipitation by iron and aluminum (Vymazal, 2007; Kadlec and Wallace, 2008; Mitsch and Gosselink, 2011). Among the processes, accretion of soil/peat is a nonsaturating phosphorus removal mechanism, which allows wetlands to function as long-term phosphorus sinks (Knight et al., 2003; Vymazal, 2007). Despite the fact that wetlands provide a range of ecological functions and services, their area of coverage and quality have been on the decline globally (Gardner et al., 2015). In the contiguous United States, more than half of the 
historical wetlands have been lost, primarily due to agricultural conversion (Dahl, 1990). However, because of the unique ecological and water quality functions wetlands provide, there is an increasing interest in wetland restoration (Zedler, 2000; Boesch, 2006; Mitsch and Day Jr, 2006).

Previous studies have also shown that the impact of management practices, including wetlands, vary based on their size, distance to the watershed outlet and the stream order (Marinez-Martinez et al., 2014; Marinez-Martinez et al., 2015; Giri et al., 2015). Martinez-Martinez et al. (2014) evaluated the impact of wetland area, depth, and stream order on streamflow reduction. They found that wetland depth has a minimal impact, while wetlands with larger surface areas resulted in more peak flow reduction. Overall, wetlands with larger areas and smaller depths are preferable for streamflow regulation. In terms of stream order, Marinez-Martinez et al. (2014) found that wetlands located on stream order one (headwater), had a much greater impact on peak flow reduction than wetlands located on higher order streams. Martinez-Martinez et al. (2015) also evaluated the impact of stream order and distance to outlet of four wetland sizes on sediment load reduction. In terms of distance to outlet, wetlands located at mid-range distance from the outlet had the highest sediment load reduction at the watershed level. Considering stream order, wetlands located on fourth order streams were the most efficient in sediment load reduction at the watershed scale. In terms of phosphorus load reduction, Giri et al. (2015) evaluated the efficiency of five management practices (including strip cropping, residue management, conservation tillage, native grass, and no-till) on phosphorus load mitigation. They found that the impact of management practices on phosphorus reduction varied by the type of management practices. For example, strip cropping, residue management, and native grass managements placed in the middle of the watershed resulted in lower phosphorus reduction than other locations 
at the outlet, while conservation tillage and no-till practices resulted in higher phosphorus load reduction at the outlet when placed in the middle of the watershed (Giri et al., 2015). In terms of stream order, the results showed that management practices placed on first and second order streams are the most efficient for phosphorus reduction at the outlet (Giri et al., 2015).

Unlike constructed wetlands, which receive controlled and measured inflows, restored/natural wetlands receive unregulated inflow and hence, their nutrient removal capabilities are difficult to measure (Jordan et al., 2003). In addition, at the watershed scale, it is infeasible and costly to study the wetland water quality improvement effects over time (Wang et al., 2010). Under such circumstances, models provide valuable tools for evaluating different restoration scenarios and placement options.

Researchers have used various modeling approaches, including the Soil and Water Assessment Tool (SWAT) (Wang et al., 2008; Feng et al., 2013; Almendinger et al., 2014; MartinezMartinez et al., 2014 and 2015), Hydrological Simulation Program-Fortran (HSPF) (Schwar, 1998; Filoso et al., 2004; Zhang et al., 2009; Liu et al., 2011), MIKE-SHE (Copp and Nath, 2004; Thompson et al., 2004; Dai et al., 2010) and DRAINMOD (Caldwell et al., 2007; Jia and Luo, 2009) to simulate wetland processes at watershed scales. Among these models, SWAT (Arnold et al., 1998) is the most widely used watershed and river basin scale water quality model and has been extensively used to simulate hydrology, sediment and nutrient transport, and scenario analyses (Gassman et al., 2014). One major shortcoming of the SWAT model in simulating wetlands is that it assumes instantaneous mixing and the sole method for nutrient removal is settling (Neitsch et al., 2011). This is not completely true since wetlands are not completely mixed systems and other processes, such as plant uptake, chemical reactions and transformations, also contribute to nutrient removal in the wetlands (Kadlec and Wallace, 2008). 
To overcome the drawbacks in representing wetlands, coupling the SWAT model with the System for Urban Stormwater Treatment and Analysis Integration (SUSTAIN) model (Shoemaker et al., 2009) is recommended, allowing the incorporation of natural wetland performance data into the modeling process (Martinez-Martinez et al., 2015). Martinez-Martinez et al. (2015) used coupled SWAT and SUSTAIN models for assessing wetland implementation scenarios on streamflow and sediment load mitigation. However, no modeling study has been conducted on the assessment of wetland impacts on phosphorus reduction. The goals of this study are to: 1) assess the impacts of wetland restoration scenarios on phosphorus reduction at the subwatershed and watershed levels; 2) evaluate the importance of wetland size, stream order and distance to the outlet on phosphorus reduction; and 3) provide a wetland implementation guideline for policy makers considering both economic and environmental aspects of wetland restoration scenarios.

\section{Materials and methods}

\subsection{Study area}

The Saginaw River Watershed, the largest 6-digit Hydrological Unit Code (HUC-6) watershed in Michigan, was selected as the study area. With the total drainage area of $16,120 \mathrm{~km}^{2}$, it drains to Lake Huron (Figure 1-a). Agricultural lands cover more than $46 \%$ of the study area, followed by forest lands (37.5\%), wetlands and water (9\%), arid, transportation, and urban lands (7.5\%). The U.S. Environmental Protection Agency (U.S. EPA) has identified the Saginaw River Watershed as an area of concern due to polluted sediment and degraded fisheries (U.S. EPA, 2015); making wetland and habitat restorations a priority for this region (U.S. EPA, 2015). 
Potential wetland restoration areas for the Saginaw River Watershed were obtained from the Michigan Department of Environmental Quality (MDEQ) (MDEQ, 2016). These areas were classified into three groups: the highest, high, and moderate wetland restoration potential depending on the occurrence of hydric soil and previous existence of wetlands before landuse changes (Figure 1-b). Areas with both hydric soil and previous existence of wetlands were classified as the highest potential for wetland restoration. Areas with only hydric soil were classified as high potential, whereas areas having only wetlands before landuse changes were classified as moderate. Areas with the highest potential wetland restoration areas cover more than $6 \%$ of the watershed, while high and moderate potential areas cover around $15 \%$ and $5 \%$, respectively. In this study, only areas with the highest restoration potential were considered for examining wetland restoration scenarios.

Figure 1.

\subsection{Modeling process}

Figure 2 shows the modeling process used for evaluating the impact of wetland implementation on phosphorus reduction both at the subwatershed and watershed levels. The SWAT model was setup for the study area using both physiographical (e.g. elevation, landuse, and soil type) and climatological (e.g. precipitation and temperature) data. The calibrated SWAT model was run for 10 years to simulate flow, sediment fractions (sand, silt, and clay), and phosphorus loads for each stream segment within the study area. This information along with climatological data (precipitation and temperature) were incorporated into the SUSTAIN model to evaluate the impacts of wetland sizes on total phosphorus reduction at the subwatershed level. For watershed level assessment, SUSTAIN output (phosphorus load untreated by the wetland) were routed into 
the SWAT model as point sources and their impact on the phosphorus reduction was evaluated at the watershed outlet.

Figure 2.

\subsection{SWAT model setup}

SWAT is a semi-distributed continuous time watershed/water quality model developed by U.S. Department of Agriculture (USDA) Agricultural Research Service (ARS) for evaluation of land management practices impact on streamflow, sediment, nutrient, and chemical yields at the watershed scale (Neitsch et al., 2011). SWAT uses topography, landuse, soil, climate and agricultural management practices to simulate long-term water quantity and quality parameters for all stream segments of a watershed on a daily basis (Arnold et al., 1998; Gassman et al., 2007). In this study, SWAT version 2012 (revision 612) was run for the period of 1998 to 2009 to estimate daily streamflow, sediment and total phosphorus (TP) loads. The first two years were used for the model warm-up and the results were not used for further analysis.

\subsubsection{SWAT model input data}

In this study, predefined watershed delineation developed by Michigan Institute for Fisheries Research (IFR) was used, dividing the Saginaw watershed into 13,831 subwatersheds (Figure 3). Digital elevation data was obtained from the National Elevation Dataset (NED, 2015) at 1/3 arcsecond spatial resolution. Cropland data layer, at 30-meter resolution, representing the landuse/land cover data of Michigan in 2014 was downloaded from USDA National Agricultural Statistics Service (NASS) (NASS, 2015). Soil data was obtained in the form of the Soil Survey Geographic Database (SSURGO) from the U.S. Department of Agriculture (USDA) Natural 
Resources Conservation Service (NRCS) (SSURGO, 2014). Soil data were collected for the scale range of $1: 12,000$ to $1: 63,360$ and includes information such as soil reaction, conductivity, water capacity and flood frequency (NRCS Soils, 2016). Climate data, including daily precipitation and (minimum and maximum) temperatures were obtained from the National Oceanic and Atmospheric Administration (NOAA), National Centers for Environmental Information (NCEI) for 16 weather stations within and around the study area shown in Figure 3 for the period of January 1998 to December 2009 (NCEI, 2016). Daily streamflow data were obtained from the U.S. Geological Survey (USGS) National Water Information System for nine monitoring sites shown in Figure 3 (USGS, 2016). However, since, none of these stations had enough water quality samples, a USGS station (04157000) near the most downstream streamflow monitoring site (04157005) was used for water quality calibration. For stream flow, enough measurements were available; however, only 28 sediment and TP measurements were available for the period of 1998-2005. Therefore, the LOADEST model developed by U.S. Geological Survey was used to create monthly sediment and TP loads. LOADEST is a load estimator program developed by USGS, that uses regression models including Maximum Likelihood Estimation (MLE), Adjusted Maximum Likelihood Estimation (AMLE), and Least Absolut Deviation (LAD) for constituent load estimation (Runkel et al., 2004). These regression models estimate monthly loads based on streamflow time series and limited monitored constituent concentrations (Runkel et al., 2004). Among the three developed models, MLE and AMLE are recommended when the model residuals are normally distributed, while LAD predictions are used when residuals are not normally distributed (Runkel et al., 2004). The advantage of AMLE compared to MLE is that it handles censored data better, while for uncensored data both are the same. Using monitored water quality and quantity, regression 
models were developed for sediment and TP monthly loads. The AMLE model was selected for the sediment and the LAD regression model was selected for TP loads prediction based on the residuals distributions. The highest $R^{2}$ achieved for sediment and TP were 0.92 and 0.89 , respectively. The models' outputs were later used for sediment and TP loads calibration/validation.

\subsubsection{Calibration and validation criteria}

The SWAT model was calibrated and validated for streamflow, sediment, and TP loads. Daily observed flow time series for nine USGS stations (Figure 3) from 2001 to 2008 (four years calibration and four years validation) where used for streamflow calibration. Three statistical criteria recommended by Moriasi et al. (2007) for watershed model evaluation were used in this study. These criteria are: 1) Nash-Sutcliffe efficiency (NSE) representing the ratio of residual variance to the actual data variance, 2) Percent bias (PBIAS) measuring tendency of simulated results to be larger or smaller than observed values, and 3) The ratio of root-mean-square error to observed standard deviation ratio (RSR) (Moriasi et al., 2007). In regard to flow, NSE above 0.50 , PBIAS in the range of $\pm 25 \%$, and RSR below 0.70 are defined as satisfactory (Moriasi et

al., 2007). NSE and RSR satisfactory ranges for sediment and phosphorus were the same as streamflow, while PBIAS in the range of $\pm 55 \%$ for sediment and $\pm 70 \%$ for phosphorus (Moriasi et al., 2007).

Figure 3.

\subsection{SUSTAIN model}


SUSTAIN is a decision support model developed by the U.S. EPA for evaluation of Best Management Practice (BMP) implementation at the watershed level (Shoemaker et al., 2009). SUSTAIN is able to evaluate the impact of BMPs including point BMPs (e.g. wetland), linear BMPs (e.g. vegetated filter strip), and area BMPs (e.g. green roof) on surface run-off and sediment and nutrient load reduction (U.S. EPA 2016). Inputs to the wetland module of the SUSTAIN model include climate, sediment fractions (sand, silt, and clay), flow, and nutrients loads. The module is able to accommodate several pollutant removal processes in wetlands including completely mixed, Continuous Stirred Tank Reactors (CSTRs) in series, or Plug Flow Reactor (PFR) (Shoemaker et al., 2009). Pollutant removal rate can also be calculated using first order decay or Kadlec and Knight's ( $\left.K-C^{*}\right)$ method (Kaldec and Knight, 1996).

\subsubsection{Wetlands implementation in SUSTAIN model}

In this study, wetlands were used as BMPs for phosphorus load reduction. Subwatersheds with the highest wetland restoration potential (Figure 3) were selected for this purpose. For each subwatershed, four different wetland sizes $(2,4,6$, and 8 hectares) were implemented one at a time. The wetland sizes were recommended by the U.S. Army Corp of Engineers for the study area. The subwatersheds with the restoration potential area below 8 ha (which was the maximum wetland size) were not considered in this study. In addition, subwatersheds that had wetlands, water or urban areas as the dominant landuse type, were not considered for wetland restoration. Figure 3 shows 2,293 subwatersheds out of 13,831 that were used for wetland implementation scenarios.

SWAT simulated surface run-off, sediment, and TP loads at the subwatershed level. This information along with climate were used as inputs to SUSTAIN model. In this study, SUSTAIN used three CSTR in series for phosphorus routing and the $K-C^{*}$ model (Kaldec and Knight 
1996) for phosphorus removal calculation. Phosphorous removal rate $(K)$, and background concentration $\left(C^{*}\right)$ were set to $10 \mathrm{~m} /$ year and $0.002 \mathrm{mg} / \mathrm{l}$ respectively. These values were selected as median rates reported by Kaldec and Wallace (2008). The length to width ratio of 2:1 and wetland depth of $0.3 \mathrm{~m}$ were used as recommended by previous studies (Martinez-Martinez et al., 2015). SUSTAIN was run four times, one for each wetland size, for the 2,293 selected subwatersheds resulting in $2293 \times 4=9172$ total runs. Comparison of SUSTAIN inputs and outputs indicate the impact of wetland implementation on TP reduction at the subwatershed level.

In order to determine the impact of individual wetlands on TP reduction at the watershed level, the outputs from each SUSTAIN model were incorporated into the SWAT as a point source for the given subwatershed. At the same time, pollution loads from the given subwatershed were eliminated by zeroing the precipitation for the studied subwatershed. Then SWAT was run for each individual wetland scenario, a total of 9,172 SWAT runs. Comparison of TP load with the base scenario (no wetland implemented) at the watershed outlet shows the total amount of TP reduction at the watershed level from each wetland scenario.

\subsection{Individual environmental and economic aspects of wetland restoration scenarios}

In order to develop a viable wetland restoration plan, both environmental and economic aspects should be considered. Regarding the environmental benefits of wetland restoration scenarios, statistical analyses were performed to identify suitable wetlands for each subwatershed based on size and location (stream order and distance to the watershed outlet). The average annual TP reduction at each group of wetlands (categorized by size, stream order and distance to outlet) were compared using the Fisher's Least Significant Difference test (Williams and Abdi, 2010) at a significance level of 0.05 . 
Regarding the economic costs of wetland restoration scenarios, the SUSTAIN model can be used. However, SUTAIN does not account for site specific costs for wetland installation and maintenance (Martinez-Martinez et al., 2015). Therefore, site-specific cost information was obtained from the Michigan Natural Resources Conservation Service (NRCS) (USDA-NRCS, 2015). This information was created based on the 2013 statewide survey. Summary of costs calculations for the four-wetland sizes of 2, 4, 6 and 8 ha with a depth of $0.3 \mathrm{~m}$ are provided in Tables A1 to A4. The average costs of four wetlands were $\$ 21,625, \$ 43,249, \$ 64,874$, and $\$ 86,499$, respectively. These four costs along with the associated TP reductions were used by a Multi Criteria Decision Making (MCDM) method called VIKOR (Opricovic and Tzeng, 2004) to find the most suitable wetland size and site.

\subsection{Combined environmental and economic aspects of wetland restoration scenarios}

VIKOR can be used for complex decision-making problems with conflicting criteria (Opricovic and Tzeng, 2004). VIKOR uses an aggregated function representing the closeness to the ideal result and determines a compromise solution, providing a maximum group utility for the majority and a minimum of an individual regret for the opponent (Opricovic and Tzeng, 2007; Opricovic, 2009). The VIKOR method has been used in watershed analysis (Chang and Hsu, 2009; Chang and Hsu, 2011; Opricovic, 2011; Chang and Lin, 2014; Malekian and Azarnivand, 2016); however, this method has not been tested for allocation of agricultural best management practices such as wetlands. In this study, there are two conflicting criteria in terms of

environmental and economic factors (phosphorous reduction: benefit criterion and implementation cost: cost criterion). The VIKOR optimization method can provide efficient ranking and compromise solutions for the best alternative (wetland) selection. 
The multi-criteria measure for compromise ranking can be developed from the LP-metric used as an aggregating function in a compromise programming method (Opricovic and Tzeng, 2004). Assume $\left\{A_{1}, A_{2}, \ldots, A_{i}, \ldots, A_{m}\right\}$ be a set of $m$ possible alternatives for the decision maker, and $\left\{g_{1}, g_{2}, \ldots, g_{j}, \ldots, g_{n}\right\}$ be a set of $n$ conflicting criteria for each alternative, the generic form of a multi-criteria decision making matrix is as follows:

$\left[\begin{array}{ccc}f_{11} & \cdots & f_{1 n} \\ \vdots & \ddots & \vdots \\ f_{m 1} & \cdots & f_{m n}\end{array}\right]$

where, $f_{i j}$ is the value of the $i^{\text {th }}$ alternative $\left(A_{i}\right)$ and the $j^{\text {th }}$ criterion $\left(g_{j}\right)$. In this study, there are four alternative wetlands $(m=4)$, with two criteria $(n=2)$ for each subwatershed.

The basic principle of VIKOR is determining the positive-ideal solution $\left(f_{j}^{*}\right)$ as well as the negative-ideal solution $\left(f_{j}^{-}\right)$. The positive ideal and negative ideal solutions are the best and the worst values of alternatives according to the cost criteria or benefit criteria. In the VIKOR method, assuming that each alternative is evaluated according to each criterion, the compromise ranking could be performed by comparing the measure of closeness to the ideal alternative (Opricovic and Tzeng 2007). Development of the VIKOR method is initiated with applying the following form of the LP-metric aggregate function (Equation 1), which was proposed by $\mathrm{Yu}$ (1973) for the compromise ranking:

$L_{P, i}=\left\{\sum_{j=1}^{n}\left[w_{j} \cdot\left(\frac{\left(f_{j}^{*}-f_{i j}\right)}{\left(f_{j}^{*}-f_{j}^{-}\right)^{P}}\right]^{1 / P} \quad ; \quad 1 \leq P \leq \infty\right.\right.$

Where $w_{j}$ is the weight of $j^{\text {th }}$ criterion. $L_{P=1, i}$ (also known as $S_{i}$ ) measures the sum of deviations and evaluates the maximum group utility or majority (concordance), while $L_{P=\infty, i}$ (also known as 
$R_{i}$ ) returns the maximum deviation and represents the minimum individual regret of the opponent (discordance) (Opricovic and Tzeng 2004). So, the solution obtained by $S_{i}$ (minimum $S_{i}$ ) has the maximum group utility, and the solution obtained by $R_{i}$ (minimum $R_{i}$ ) has the minimum individual regret of the opponent.

The compromise ranking algorithm of the VIKOR method has the following steps (Opricovic and Tzeng 2004):

1) Determining $f_{j}^{*}$ and $f_{j}^{-}$values for all criterion. (in this case: $j=1,2$ )

2) Computing $S_{i}$ and $R_{i}$ values for all alternatives (in this case: $i=1,2,3,4$, and $n=2$ ) using Equations 2 and 3.

$$
\begin{aligned}
& S_{i}=\sum_{j=1}^{n} w_{j} \cdot\left(\frac{\left|f_{j}^{*}-f_{i j}\right|}{\left|f_{j}^{*}-f_{j}^{-}\right|}\right) \\
& R_{i}=\max _{j=1,2, . ., n}\left[w_{j} \cdot\left(\frac{\left|f_{j}^{*}-f_{i j}\right|}{\left|f_{j}^{*}-f_{j}^{-}\right|}\right)\right]
\end{aligned}
$$

3) Computing the values of $Q_{i}$ for all alternatives (in this case, $i=1,2,3,4$, and $n=2$ ) using Equation 4.

$Q_{i}=\vartheta \cdot \frac{\left(S_{i}-S^{*}\right)}{\left(S^{-}-S^{*}\right)}+(1-\vartheta) \cdot \frac{\left(R_{i}-R^{*}\right)}{\left(R^{-}-R^{*}\right)}$

Where $S^{*}$ and $S^{-}$are the minimum and maximum $S_{i}$ values, and $R^{*}$ and $R^{-}$are the minimum and maximum $R_{i}$ values respectively.

The parameter of $\vartheta$ is introduced as the strategy weight for the majority of criteria (or the maximum group utility) and $(1-\vartheta)$ is the weight of individual regret. The compromise can be selected with consensus $(\vartheta=0.5)$, voting by majority $(\vartheta>0.5)$, or veto $(\vartheta<0.5)$. In this study, consensus was considered, which means the same weight was considered for the effect of $S_{i}$ (maximum group utility) and $R_{i}$ (minimum individual regret of the opponent) in the decision 
making. This is the common approach for a compromise solution in MCDM problems (Opricovic and Tzeng, 2007; Sayadi et al., 2009).

4) Ranking the alternatives based on ascending $S, R$, and $Q$ values in separate lists.

5) Proposing alternative $A^{\prime}$ that has a minimum $Q$ value as a compromise solution if the following two conditions are satisfied:

Condition 1: Acceptable advantage, meaning that the difference of the first two ranked alternatives by $Q\left(\mathrm{~A}^{\prime}:\right.$ the first rank, and $A^{\prime \prime}$ : the second rank) satisfy Equation 5.

$$
Q\left(A^{\prime \prime}\right)-Q\left(A^{\prime}\right) \geq D Q
$$

where, $D Q=1 /($ number of alternatives -1$)$.

Condition 2: Acceptable stability in decision making, meaning that $A^{\prime}$ alternative must also be the best ranked alternative by the $S$ or/and $R$ measures.

If one of these two conditions is not satisfied, then a set of compromise solutions are proposed including:

○ Alternatives $A^{\prime}$ and $A^{\prime \prime}$ if only Condition 2 is not satisfied, or

o Alternatives $\left\{A^{\prime}, A^{\prime \prime}, \ldots, A^{(M)}\right\}$ if Condition 1 is not satisfied. Where $A^{(M)}$ is determined by the following relation for maximum $\mathrm{M}$

$$
Q\left(A^{(M)}\right)-Q\left(A^{\prime}\right)<D Q
$$

In this study, for the cases that both conditions were not satisfied and a set of alternatives were proposed, the smallest wetland size was preferred.

\section{Results and discussion}

\subsection{SWAT model calibration and validation}


Table 1 shows that NSE, PBIAS and RSR for all stations are within the satisfactory range, meaning that streamflow was successfully calibrated and model simulations are reliable.

\section{Table 1.}

Regarding sediment and total phosphorus, NSE, PBIAS, and RSR were calculated for eight years starting from 1998 to 2005 (four years calibration and four years validation). Table 2 shows that NSE, PBIAS, and RSR are all within the satisfactory range, meaning that the SWAT model sediment and TP loads are reliable.

\section{Table 2.}

\subsection{Individual environmental and economic aspects of wetland restoration scenarios}

In order to help watershed managers to better understand the environmental aspects of wetland restoration scenarios at the subwatershed and watershed levels, three sets of analyses were performed that include evaluation of the significance of TP reduction based on: 1) wetland sizes; 2) stream order and wetland size; and 3) distance from the watershed outlet and wetland size.

\subsubsection{The impacts of wetland size on TP mitigation}

Figures 4 and A2 show the percentage of TP reduction at the subwatershed and watershed levels for each of the four sizes of wetlands implemented one at the time on the 2,293 selected subwatersheds. Average annual TP reductions were calculated over ten water years starting from October 1999 to September 2009. Figure 4 shows that wetlands have huge impacts on TP mitigation at the subwatershed level. For the majority of subwatersheds (especially for wetland sizes of 6 ha and 8 ha), wetland implementation resulted in more than $75 \%$ reduction in TP load generated at the subwatershed. Furthermore, wetland performances were improved by using 
larger wetlands. For wetlands with a size of 2 ha, only $0.1 \%$ of the subwatersheds had TP reductions below $25 \%$ and less than $3 \%$ of the subwatersheds had TP reductions below $50 \%$ (Figure 4-a). While for larger wetland sizes all subwatersheds had more than $25 \%$ TP reduction (Figure 4-b, c, \& d). Furthermore, for 4 ha and 6 ha wetlands TP reduction in the range of 25\%$50 \%$ was seen in only $0.5 \%$ and $0.1 \%$ of the subwatersheds, respectively (Figure 4-b \& c). While for 8 ha wetlands phosphorous reductions never dropped below 50\% (Figure 4-d). This shows that TP reduction increased with increasing wetland size.

Figure 4.

Compared to the subwatershed level, the impact of implemented wetlands on TP reduction at the watershed outlet was minimal (Figure A2). Maximum reduction observed in the watershed outlet was $0.16 \%$ and most of the wetlands $(96 \%)$ had less than $0.04 \%$ impact on TP load at the outlet, which was expected due to small size of the wetlands (maximum 8 ha) compared to the total watershed area $\left(16,120 \mathrm{~km}^{2}\right.$ or $\left.1,612,000 \mathrm{ha}\right)$. The difference between load reduction at the subwatershed level and the watershed level is also in agreement with previous studies on streamflow and sediment load reduction (Martinez-Martinez et al., 2014; Martinez-Martinez et al., 2015).

Table 3 shows the average annual TP load reduction $(\mathrm{kg})$ for the four wetland sizes. As was expected, using larger wetlands increased the average reduction both at the subwatershed level and the watershed level. At the subwatershed level, 8 ha wetland implementation resulted in significantly higher average reduction than implementation of 2 ha and 4 ha wetlands, and 4 ha wetland implementation caused significantly higher average reduction than 2 ha wetlands. While the average annual reduction by 6 ha wetlands was not significantly different from 4 ha and 8 ha wetlands. This means that 6 ha wetlands do not reduce phosphorous loads significantly better or 
worse when compared to the phosphorous reductions associated with smaller (4 ha) or larger (8 ha) wetlands, so there would be less interest in using this size of wetland rather than the two adjacent sizes for TP reduction at the subwatershed level. Additionally, the 2 ha wetland implementation resulted in significantly lower average load reduction compared to larger wetlands, which make it less desirable for TP load mitigation at the subwatershed level.

\section{Table 3.}

Similar to the subwatershed level, larger wetland sizes resulted in more TP load reduction at the watershed level as well, however less variation was observed among the different wetland sizes (Table 3). Load reduction at the outlet was not significant between the 4,6 , and 8 ha wetlands, while their values were significantly higher than the reduction by the 2 ha wetlands. Meaning that wetlands of either of these three sizes could be implemented a produce similar results when looking at the watershed level TP reduction. Besides that, average TP load reductions at the watershed level are much lower than the average TP load at the watershed outlet $(248,282 \mathrm{~kg})$ for the given time period (October 1999 - September 2009). This is in agreement with Figure A2, showing that implemented wetlands had a small impact (less than $0.16 \%$ ) on lowering the TP load. This is also in agreement with Giri et al. (2012) results showing that the impact of BMPs on TP reduction at the watershed level is less than subwatershed level.

\subsubsection{The impacts of wetland implementation site based on stream order and size on TP} mitigation

Tables 4 and A7 summarize the TP reduction at the subwatershed and watershed levels for the four wetland sizes located in different stream orders. Since there are few streams with orders of 6 and 7, those are grouped together and represented as one class. Horizontal comparisons show the 
impact of wetland size on TP reduction for each stream order, while vertical comparisons represent how a given wetland size mitigates TP load among different stream orders.

\section{Table 4.}

Horizontal comparisons (within a specific stream order) at the subwatershed level and watershed level show that higher reductions occur for larger wetlands; however, in general, there is no noticeable difference in reductions achieved by the different wetland sizes. For stream orders of 4,5 , and $6 \& 7$, TP reduction was not significantly affected by the wetland size at either the subwatershed level or the watershed level. For $2^{\text {nd }}$ and $3^{\text {rd }}$ stream orders at the subwatershed level, wetland sizes of 6 ha and 8 ha had significantly higher reduction than wetland size of 2 ha. Similar differences among reductions caused by wetland sizes of 8 ha and 2 ha were observed for stream orders 1 and 3 at the watershed level, while reductions achieved by wetland sizes of 4 ha and 6 ha were not significantly different from either the 2 ha or 8 ha wetland reductions.

In contrast to the horizontal comparisons, vertical comparisons (between stream orders) show that for a given wetland size, change in the stream order resulted in significant variations in the TP reduction. Table 4 shows that at the subwatershed level, wetlands located in subwatersheds with stream order of 5 have the maximum average reduction, followed by stream order 1 and stream orders $6 \& 7$. Minimum reductions were observed for subwatersheds with stream order 2, which were significantly lower than the reductions for $5^{\text {th }}$ order streams, regardless of wetland size. These results show that in general, wetlands implemented in headwater streams and downstream performed better than those in midsize streams. Martinez-Martinez et al. (2015) also found that wetlands placed in the headwaters and downstream were more effective than those placed in the middle of the watershed for sediment mitigation. Similar results were observed at the watershed level (Table A7), where stream orders $6 \& 7$ had the maximum reduction, followed 
by stream orders 5 and 1 . Besides that, reductions achieved for stream orders of 2, 3, and 4 were significantly lower than the reductions of stream orders 1 and 5, that again show the advantage of implementing wetlands on downstream and headwater streams rather than midsize streams.

\subsubsection{The impacts of wetland implementation site based on distance to the watershed outlet and} size on TP mitigation

Tables 5 and A8 show the summary of statistical analysis on average TP reduction based on wetland sizes and distances to the watershed outlet at the subwatershed and watershed levels. Wetlands have been divided in to five groups based on their distance from the outlet varying from 0 to $250 \mathrm{~km}$.

\section{Table 5.}

Similar to the wetlands classification based on the stream order, few significant changes in TP reduction were observed, with respect to wetland size, for wetlands located the same distance from the outlet. For wetlands located very close $(0-50 \mathrm{~km})$ to the outlet, or very far (200-250 $\mathrm{km}$ ) from it, change in wetland size had no significant impact on the TP reductions both at the subwatershed level and the watershed level, while for middle distances, wetland size had a significant impact. At the subwatershed level, for wetlands in the distance ranges of 50-100 km and 100-150 km, reductions achieved in 4 ha, 6 ha, and 8 ha wetlands were significantly higher than the reductions of 2 ha wetlands. In addition, for the distance range of 150-200 km, 6 ha and 8 ha wetlands had significantly more reduction than 2 ha wetlands (Table 5). At the watershed level, 2 ha wetlands had significantly lower reduction than 6 ha and 8 ha wetlands for distance ranges of $100-150 \mathrm{~km}$ and $150-200 \mathrm{~km}$, while no significant difference in reduction was observed between all four wetland sizes for the distance range of 50-100 km (Table A8). These results show that wetlands in the distance range of $50 \mathrm{~km}$ to $200 \mathrm{~km}$ are more sensitive to the 
wetland size, while wetlands located farther $(200-250 \mathrm{~km})$, or closer $(0-50 \mathrm{~km})$ from the outlet were not sensitive to the wetland size.

Vertical comparison (between distances) revealed variations in TP reduction within the same size wetlands located at different distances form the outlet. Both at the subwatershed and watershed levels, wetlands located close to the outlet $(0-50 \mathrm{~km})$ had significantly lower reductions for all four wetland sizes, meaning that subwatersheds in this range are less effective for wetland implementation. At the subwatershed level, wetlands in the farthest distance $(200-250 \mathrm{~km}) \mathrm{had}$ significantly higher reductions followed by wetlands in the middle distance range (100-150 km), while at the watershed level wetlands in the ranges of $50-100 \mathrm{~km}$ and $100-150 \mathrm{~km}$ from the outlet had higher reductions than those that were farther from the outlet. This means that at the watershed level, wetlands located in the middle of watershed have the most impact on TP reduction at the watershed outlet. This is similar to the results found by Giri et al. (2015), where the implementation of conservation tillage and no till BMPs in subwatersheds in the middle of watershed reduced TP more than those located farther or closer to the watershed outlet.

\subsection{Combined environmental and economic aspects of wetland restoration scenarios}

In order to evaluate the impact of the two conflicting criteria on decision making, nine scenarios $(0.1 / 0.9,0.2 / 0.8,0.3 / 0.7,0.4 / 0.6,0.5 / 0.5,0.6 / 0.4,0.7 / 0.3,0.8 / 0.2,0.9 / 0.1)$ were defined based on varying weights of TP reduction/wetland implementation cost. MATLAB version 2016a was used to apply the VIKOR method. Sample calculations and wetland selection for one subwatershed at the subwatershed level are provided in the supplementary materials. A similar process was repeated for all 2,293 subwatersheds at both the subwatershed and watershed levels for the nine reduction/cost scenarios (Figures 5 and A3). The spatial distribution of the selected wetlands are also shown in Figures 6 and A4. 
At the subwatershed level, for first three scenarios of 0.1/0.9, 0.2/0.8 and 0.3/0.7, 2 ha wetlands were preferred to other alternatives for all 2,293 subwatersheds (Figures 5 and 6). This can be explained by higher weight of the wetland cost to TP reduction, meaning that the smallest wetland size (with the minimum implementation cost) is highly preferred even if it causes less reduction than other wetland sizes. Similar preference for 2 ha wetland selection was seen in the first three scenarios at the watershed level (Figures A3 and A4). This absolute preference of the smallest wetland size was changed by increasing the ratio of reduction/cost weights from 0.4/0.6. For the 0.4/0.6 scenario, 4 ha wetlands were preferred over 2 ha wetlands for some subwatersheds, however, the number of selected wetlands and their distribution was not the same for the subwatershed and watershed level studies. At the subwatershed level, 4 ha wetlands were selected more often than 2 ha wetlands (Figure 5), while at the watershed level 2 ha wetlands were more preferred (Figure A3). Comparison of Figure 6-d and Figure A4-d show that the spatial distribution of 4 ha wetlands at the watershed level were not necessarily the same subwatersheds selected at the subwatershed level. This shows how selecting different levels of study (subwatershed vs watershed) can result in different decision making analysis outcomes.

Considering equal weights for TP reduction and wetland implementation cost (0.5/0.5 scenario), the majority of wetlands selected at the subwatershed level were 4 ha followed by few 2 ha (Figure 5), while at the watershed level, three wetland sizes of 2 ha, 4 ha and 6 ha were selected (Figure A3). This again showed the impact of different levels of study on the decision making analysis. For the given scenario, 6 ha wetlands were preferred in more than $8 \%$ of subwatersheds at the watershed level, while 2 ha and 4 ha were the only favorable wetland sizes at the subwatershed level analysis. 
Increasing the ratio of reduction weight versus the cost weight made larger wetlands more favorable because larger wetlands result in more reduction both at the subwatershed and watershed levels. The number of selected subwatersheds and their distribution varied depending on the weights ratio and the level of study. For the $0.9 / 0.1$ scenario that had highest weight of reduction along with lowest weight of cost, 4 ha wetlands were dominant (more than $71 \%$ ) at the subwatershed level, followed by 6 ha wetlands (more than 26\%), while 2 ha wetlands were rarely selected (less than 2\%). At the watershed level, 4 ha wetlands were also more favorable (more than $32 \%$ ) for the $0.9 / 0.1$ scenario, followed by 6 ha (28\%), 2 ha (27\%), and 8 ha (12\%) wetlands. 8 ha wetlands were not selected at any of the subwatershed level scenarios (Figure 5), while they were selected for the $0.6 / 0.4,0.7 / 0.3,0.8 / 0.2$ and $0.9 / 0.1$ scenarios at the watershed level (Figure A3).

\section{Figure 5.}

Figure 6.

Figures 5, 6, A3, A4 provide a guideline for policy makers and stakeholders in order to select the most effective wetland size based on the desired wetland implementation scenario for either local (subwatershed level) or watershed level applications.

\section{Conclusion}

The VIKOR method was used to provide a guideline for policy makers and stakeholders for wetland implementation scenarios considering TP reduction and wetland implementation costs. Nine scenarios based on TP reduction/wetland cost weights ratio were developed. The number of each wetland size selected and their spatial distribution showed the importance of the level of study and TP reduction/wetland cost ratio on wetland selection. In general, more 2 ha wetlands 
were selected for lower TP reduction/wetland cost ratios. Decreasing the weight of cost and increasing the reduction weight, increased the number of larger wetlands selected for each scenario. The largest wetland size selected at the subwatershed level analysis was 6 ha, while at the watershed level, 8 ha wetlands were selected most often.

The procedure introduced in this study can be easily adapted in other watersheds around the world as long as a calibrated SWAT model is available for the study area. The integrated SUSTAIN-SWAT model is an important tool for watershed managers and stakeholders to make better decision regarding development of wetland restoration strategies. This study only considered the implementation of one wetland at a time, while implementing more wetlands at the same time is going to have different impacts that should be considered in future studies.

\section{Acknowledgement}

This project was supported and funded by the U.S. Army Corps of Engineers and U.S. Geological Survey under the agreement number G16AP00020.

\section{References}

Aghajani Mir, M., Taherei Ghazvinei, P., Sulaiman, N.M.N., Basri, N.E.A., Saheri, S., Mahmood, N.Z., Jahan, A., Begum, R.A., Aghamohammadi, N., 2016. Application of TOPSIS and VIKOR improved versions in a multi criteria decision analysis to develop an optimized municipal solid waste management model. J. Environ. Manage. 166, 109-115.

Almendinger, J.E., Murphy, M.S., Ulrich, J.S., 2014. Use of the Soil and Water Assessment Tool to scale sediment delivery from field to watershed in an agricultural landscape with topographic depressions. J. Environ. Qual. 43, 9-17. 
Arnold, J.G., Srinivasan, R., Muttiah, R.S., Williams, J.R., 1998. Large Area Hydrologic Modeling and Assessment Part I: Model Development1. J. Am. Water Resour. Assoc. 34, 73-89.

Boesch, D.F., 2006. Scientific requirements for ecosystem-based management in the restoration of Chesapeake Bay and Coastal Louisiana. Ecol. Eng. 26, 6-26.

Caldwell, P.V., Vepraskas, M.J., Skaggs, R.W., Gregory, J.D., 2007. Simulating the water budgets of natural Carolina bay wetlands. Wetlands 27, 1112-1123.

Chang, C.-L., Hsu, C.-H., 2011. Applying a Modified VIKOR Method to Classify Land Subdivisions According to Watershed Vulnerability. Water Resour. Manage. 25, 301-309.

Chang, C.-L., Hsu, C.-H., 2009. Multi-criteria analysis via the VIKOR method for prioritizing landuse restraint strategies in the Tseng-Wen reservoir watershed. J. Environ. Manage. 90, 32263230.

Chang, C.-L., Lin, Y.-T., 2014. Using the VIKOR method to evaluate the design of a water quality monitoring network in a watershed. Int. J. Environ. Sci. Technol. 11, 303-310.

Copp, R.S., Nath, A.K., 2004. Verification of Wetland Restoration Using Mathematical Models, in: Critical Transitions in Water and Environmental Resources Management. ASCE, pp. 1-10.

Dahl, T.E., 1990. Wetlands losses in the United States, 1780 's to 1980's. Report to the Congress. National Wetlands Inventory, St. Petersburg, FL (USA). Report No. PB-91-169284/XAB

Dai, Z., Li, C., Trettin, C., Sun, G., Amatya, D., Li, H., 2010. Bi-criteria evaluation of the MIKE SHE model for a forested watershed on the South Carolina coastal plain. Hydrol. Earth Syst. Sci. 14, 1033-1046. 
Dubrovsky, N.M., Burow, K.R., Clark, G.M., Gronberg, J.M., Hamilton, P.A., Hitt, K.J., Mueller, D.K., Munn, M.D., Nolan, B.T., Puckett, L.J., Rupert, M.G., Short, T.M., Spahr, N.E., Sprague, L.A., Wilber, W.G., 2010. The quality of our Nation's waters-Nutrients in the Nation's streams and groundwater, 1992-2004 (USGS Numbered Series No. 1350), Circular. U.S. Geological Survey.

Feng, X.Q., Zhang, G.X., Jun Xu, Y., 2013. Simulation of hydrological processes in the Zhalong wetland within a river basin, Northeast China. Hydrol. Earth Syst. Sci. 17, 2797-2807.

Filoso, S., Vallino, J., Hopkinson, C., Rastetter, E., Claessens, L., 2004. Modeling Nitrogen Transport in the Ipswich River Basin, Massachusetts, Using a Hydrological Simulation Program in Fortran (HSPF) 1. Wiley Online Library. J. Am. Water Resour. Assoc. 40 (5), 1365-1384.

Gardner, R.C., Barchiesi, S., Beltrame, C., Finlayson, C.M., Galewski, T., Harrison, I., Paganini, M., Perennou, C., Pritchard, D., Rosenqvist, A., Walpole, M., 2015. State of the World's Wetlands and Their Services to People: A Compilation of Recent Analyses. Ramsar Briefing Note No. 7. Gland, Switzerland: Ramsar Convention Secretariat.

Gassman, P.W., Reyes, M.R., Green, C.H., Arnold, J.G., 2007. The soil and water assessment tool: historical development, applications, and future research directions. T. ASABE 50, 1211-1250.

Gassman, P.W., Sadeghi, A.M., Srinivasan, R., 2014. Applications of the SWAT model special section: overview and insights. J. Environ. Qual. 43, 1-8.

Gentry, L.E., David, M.B., Royer, T.V., Mitchell, C.A., Starks, K.M., 2007. Phosphorus Transport Pathways to Streams in Tile-Drained Agricultural Watersheds. J. Environ. Qual. 36, 408-415. 
Giri, S., Nejadhashemi, A.P., Woznicki, S.A., 2012. Evaluation of targeting methods for implementation of best management practices in the Saginaw River Watershed. J. Environ. Manage. 103, 24-40.

Giri, S., Nejadhashemi, A.P., Zhang, Z., Woznicki, S.A., 2015. Integrating statistical and hydrological models to identify implementation sites for agricultural conservation practices. Environ. Modell. Softw. 72, 327-340.

Jia, Z., Luo, W., 2009. A modified climate diagram displaying net water requirements of wetlands in arid and semi-arid regions. Agr. Water Manage. 96, 1339-1343.

Jordan, T.E., Whigham, D.F., Hofmockel, K.H., Pittek, M.A., 2003. Nutrient and Sediment Removal by a Restored Wetland Receiving Agricultural Runoff. J. Environ. Qual. 32, 1534-1547.

Kadlec, R.H., 2005. Phosphorus Removal in Emergent Free Surface Wetlands. J. Environ. Sci. Heal. A 40, 1293-1306.

Kadlec, R.H., Knight, R.L., 1996. Treatment wetlands. CRC. Baca Raton, FL.

Kadlec, R.H., Wallace, S., 2008. Treatment Wetlands, Second Edition. CRC Press.

Knight, R.L., Gu, B., Clarke, R.A., Newman, J.M., 2003. Long-term phosphorus removal in Florida aquatic systems dominated by submerged aquatic vegetation. Ecol. Eng. 20, 45-63.

Liu, H.-C., You, J.-X., Fan, X.-J., Chen, Y.-Z., 2014. Site selection in waste management by the VIKOR method using linguistic assessment. Appl. Soft Comput. 21, 453-461.

Liu, Z., Tong, S.T.Y., 2011. Using HSPF to Model the Hydrologic and Water Quality Impacts of Riparian Land-Use Change in a Small Watershed. J. Environ. Inform. 17, 1-14. 
Malekian, A., Azarnivand, A., 2016. Application of Integrated Shannon's Entropy and VIKOR Techniques in Prioritization of Flood Risk in the Shemshak Watershed, Iran. Water Resour Manage. 30, 409-425.

Martinez-Martinez, E., Nejadhashemi, A.P., Woznicki, S.A., Adhikari, U., Giri, S., 2015. Assessing the significance of wetland restoration scenarios on sediment mitigation plan. Ecol. Eng. 77, $103-113$.

Martinez-Martinez, E., Nejadhashemi, A.P., Woznicki, S.A., Love, B.J., 2014. Modeling the hydrological significance of wetland restoration scenarios. J. Environ. Manage. 133, 121-134.

MDEQ, 2016. Wetlands Map Viewer, Department of Environmental Quality, URL: http://www.mcgi.state.mi.us/wetlands/ (accessed 11.18.15).

Michalak, A.M., Anderson, E.J., Beletsky, D., Boland, S., Bosch, N.S., Bridgeman, T.B., Chaffin, J.D., Cho, K., Confesor, R., Daloğlu, I., others, 2013. Record-setting algal bloom in Lake Erie caused by agricultural and meteorological trends consistent with expected future conditions. PNAS 110, 6448-6452.

Mitsch, W.J., Day Jr., J.W., 2006. Restoration of wetlands in the Mississippi-Ohio-Missouri (MOM) River Basin: Experience and needed research. Ecol. Eng. 26, 55-69.

Mitsch, W.J., Gosselink, J.G., 2011. Wetlands, 4th ed. John Wiley \& Sons.

Moriasi, D.N., Arnold, J.G., Van Liew, M.W., Bingner, R.L., Harmel, R.D., Veith, T.L., 2007. Model Evaluation Guidelines for Systematic Quantification of Accuracy in Watershed Simulations. T. ASABE 50, 885-900. 
NASS, 2015. USDA, National Agricultural Statistics Service, CropScape - Cropland Data Layer, URL: http://nassgeodata.gmu.edu/CropScape/ (accessed 11.30.15).

NCEI, 2016. National Centers for Environmental Information, National Oceanic and Atmospheric Administration, URL: http://www.ncdc.noaa.gov/ (accessed 11.30.15).

NED, 2015. The National Map: Elevation, URL http://nationalmap.gov/elevation.html (accessed 11.30.15).

Neitsch, S.L., Arnold, J.G., Kiniry, J.R., Williams, J.R., 2011. Soil and water assessment tool theoretical documentation version 2009. Texas Water Resources Institute. Technical Report No. 406.

NRCS Soils, 2016. USDA Natural Resources Conservation Service, Soils. URL: http://www.nrcs.usda.gov/wps/portal/nrcs/detail/soils/survey/geo/?cid=nrcs142p2_053627 (accessed 11.30.15).

Opricovic, S., 2011. Fuzzy VIKOR with an application to water resources planning. Expert Syst. Appl. 38, 12983-12990.

Opricovic, S., 2009. A Compromise Solution in Water Resources Planning. Water Resour. Manage. $23,1549-1561$.

Opricovic, S., Tzeng, G.-H., 2007. Extended VIKOR method in comparison with outranking methods. Eur. J. Oper. Res. 178, 514-529.

Opricovic, S., Tzeng, G.-H., 2004. Compromise solution by MCDM methods: A comparative analysis of VIKOR and TOPSIS. Eur. J. Oper. Res. 156, 445-455. 
Parry, R., 1998. Agricultural Phosphorus and Water Quality: A U.S. Environmental Protection Agency Perspective. J. Environ. Qual. 27, 258.

Runkel, R.L., Crawford, C.G., Cohn, T.A., 2004. Load estimator (LOADEST): a FORTRAN program for estimating constituent loads in streams and rivers (USGS Numbered Series No. 4-A5), Techniques and Methods.

Saaty, T.L., 1980. The Analytic Hierarchy Process. McGraw-Hill, New York.

Sayadi, M.K., Heydari, M., Shahanaghi, K., 2009. Extension of VIKOR method for decision making problem with interval numbers. Appl. Math. Model. 33(5), 2257-2262.

Schindler, D.W., Hecky, R.E., Findlay, D.L., Stainton, M.P., Parker, B.R., Paterson, M.J., Beaty, K.G., Lyng, M., Kasian, S.E.M., 2008. Eutrophication of lakes cannot be controlled by reducing nitrogen input: results of a 37-year whole-ecosystem experiment. PNAS 105, 11254-11258.

Schwar, M.T., 1998. Restoration of Rivers and Wetlands: Advancing the State of Hydrologic Design, in: Engineering Approaches to Ecosystem Restoration. ASCE, 549-554.

Sharpley, A.N., Daniel, T., Sims, T., Lemunyon, J., Stevens, R., Parry, R., 2003, Agricultural Phosphorus and Eutrophication, Second Edition (No. ARS 149).

Shoemaker, L., Riverson, J., Alvi, K., Zhen, J.X., Paul, S., Rafi, T., 2009. SUSTAIN: A Framework for Placement of Best Management Practices in Urban Watersheds to Protect Water Quality. National Risk Management Research Laboratory, Office of Research and Development, U.S. Environmental Protection Agency Washington, DC, (No. EPA/600/R-09/095). 
SSURGO, 2014. SSURGO Data Downloader (beta), URL:

https://www.arcgis.com/home/item.html?id=a23eb436f6ec4ad6982000dbaddea5ea (accessed 11.30.15).

Thompson, J.R., SøRENSON, H.R., Gavin, H., Refsgaard, A., 2004. Application of the coupled MIKE SHE/MIKE 11 modelling system to a lowland wet grassland in southeast England. J. Hydrol. 293, 151-179.

US EPA, O., 2016. System for Urban Stormwater Treatment and Analysis IntegratioN (SUSTAIN), URL: https://www.epa.gov/water-research/system-urban-stormwater-treatment-and-analysisintegration-sustain\#description (accessed 5.11.16).

US EPA, R. 05, 2015. Saginaw River and Bay Area of Concern. URL: https://www.epa.gov/saginawriver-bay-aoc (accessed 5.4.16).

USDA-NRCS, 2015. Field Office Technical Guide. URL: https://efotg.sc.egov.usda.gov/efotg_locator.aspx?map=US (accessed 6.15.16).

USGS, 2016. USGS Current Water Data for the Nation. URL: http://waterdata.usgs.gov/nwis/rt (accessed 5.6.16).

Vymazal, J., 2007. Removal of nutrients in various types of constructed wetlands. Sci. Total Environ. $380,48-65$.

Wang, X., Shang, S., Qu, Z., Liu, T., Melesse, A.M., Yang, W., 2010. Simulated wetland conservation-restoration effects on water quantity and quality at watershed scale. J. Environ. Manage. 91, 1511-1525. 
Wang, X., Yang, W., Melesse, A.M., 2008. Using hydrologic equivalent wetland concept within SWAT to estimate streamflow in watersheds with numerous wetlands. T. ASABE 51, 55-72.

Williams, L.J., Abdi, H., 2010. Fisher's least significant difference (LSD) test. Encyclopedia of research design $1-5$.

Woltemade, C.J., 2000. Ability of restored wetlands to reduce nitrogen and phosphorus concentrations in agricultural drainage water. J. Soil Water Conserv. 55, 303-309.

Yu, P.L., 1973. A Class of Solutions for Group Decision Problems. Manag. Sci. 19, 936-946.

Zedler, J.B., 2000. Progress in wetland restoration ecology. Trends Ecol. Evol. 15, 402-407.

Zhang, J., Ross, M., Trout, K., Zhou, D., 2009. Calibration of the HSPF model with a new coupled FTABLE generation method. Prog. Nat. Sci. 19, 1747-1755. 


\section{Figure Captions}

Figure 1. Study area (a) and wetland restoration potentials (b)

Figure 2. Modeling process flowchart

Figure 3. Potential subwatersheds for wetland restoration in the Saginaw River Watershed

Figure 4. Percentage of TP reduction at subwatershed level for wetland size of a) 2 ha, b) 4 ha, c) 6 ha and d) 8 ha

Figure 5. Most favorable wetlands selected by VIKOR considering TP reduction and wetland cost at subwatershed level

Figure 6. Most favorable wetlands selected for a) $0.1 / 0.9$, b) $0.2 / 0.8$, c) $0.3 / 0.7$, d) $0.4 / 0.6$, e) $0.5 / 0.5$, f) $0.6 / 0.4$, g) $0.7 / 0.3$, h) $0.8 / 0.2$ and i) $0.9 / 0.1 \mathrm{TP}$ reduction/wetland cost scenarios at subwatershed level 


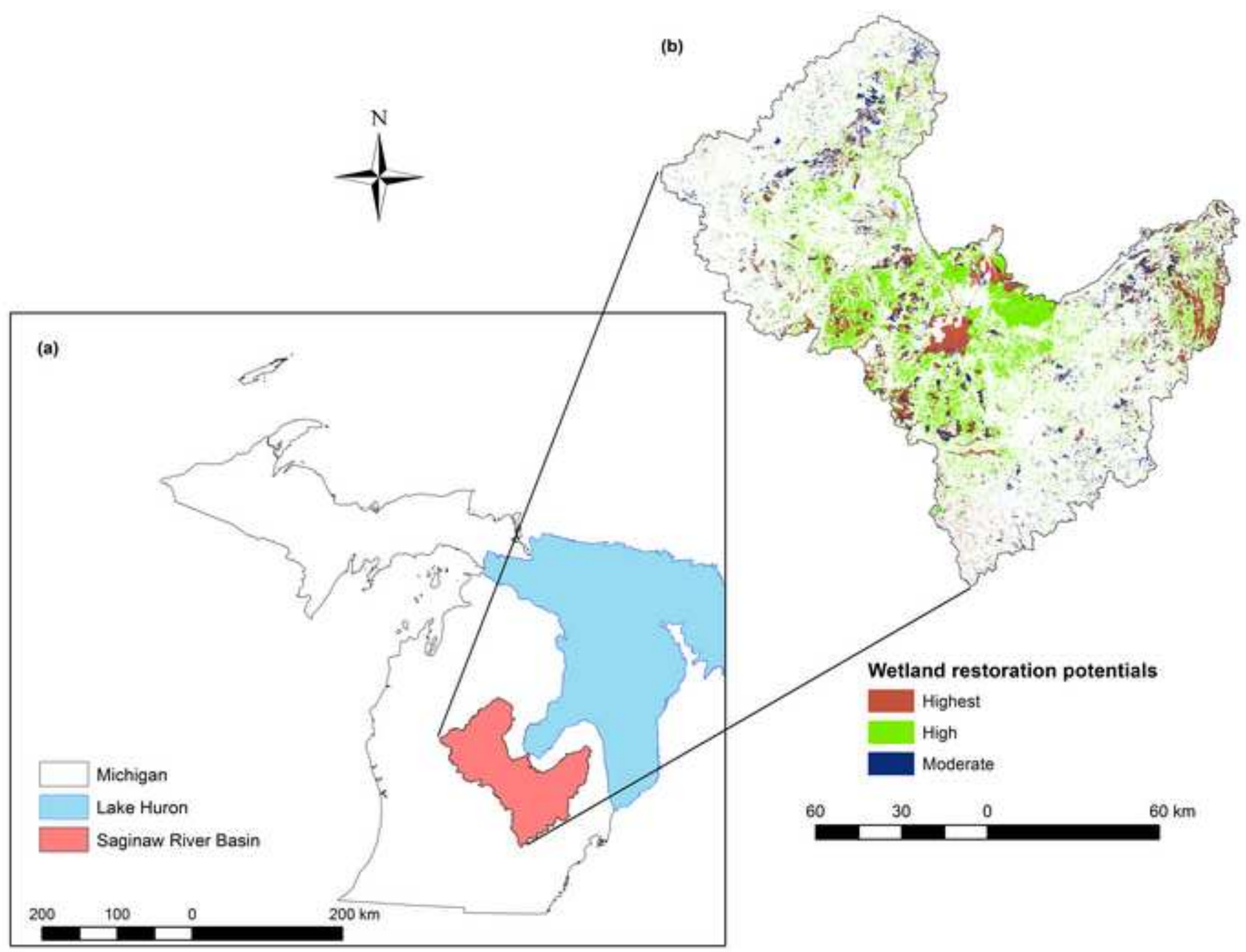




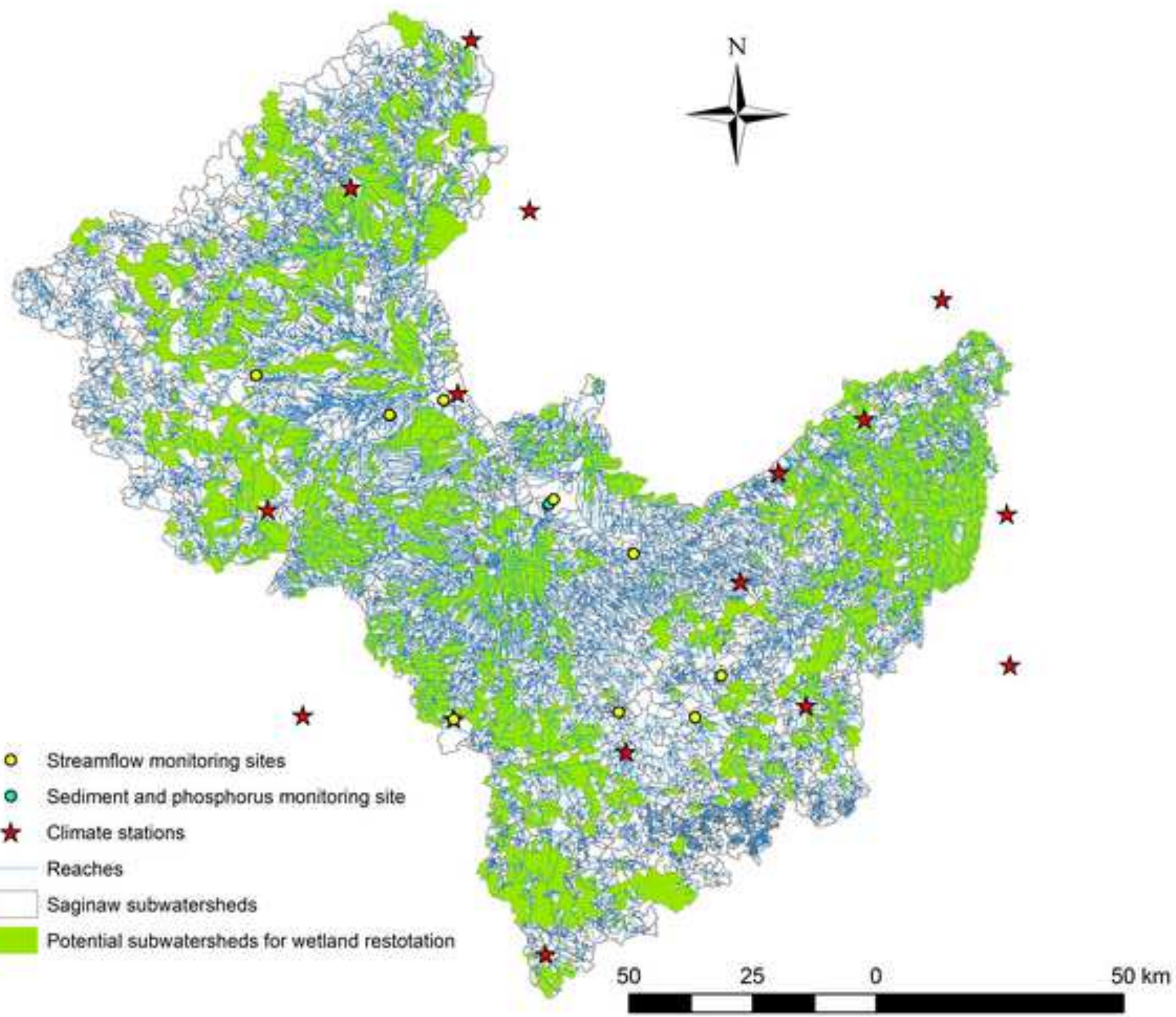


(a)

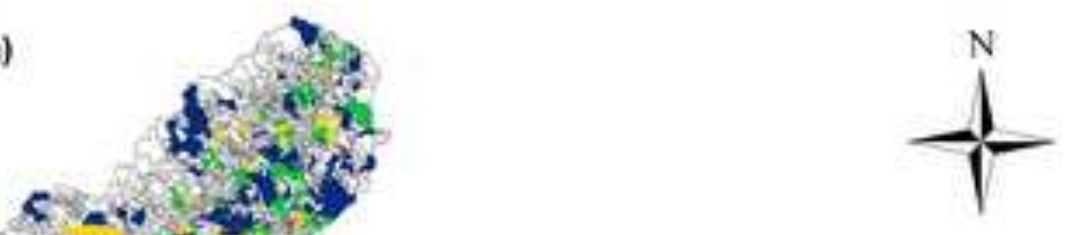

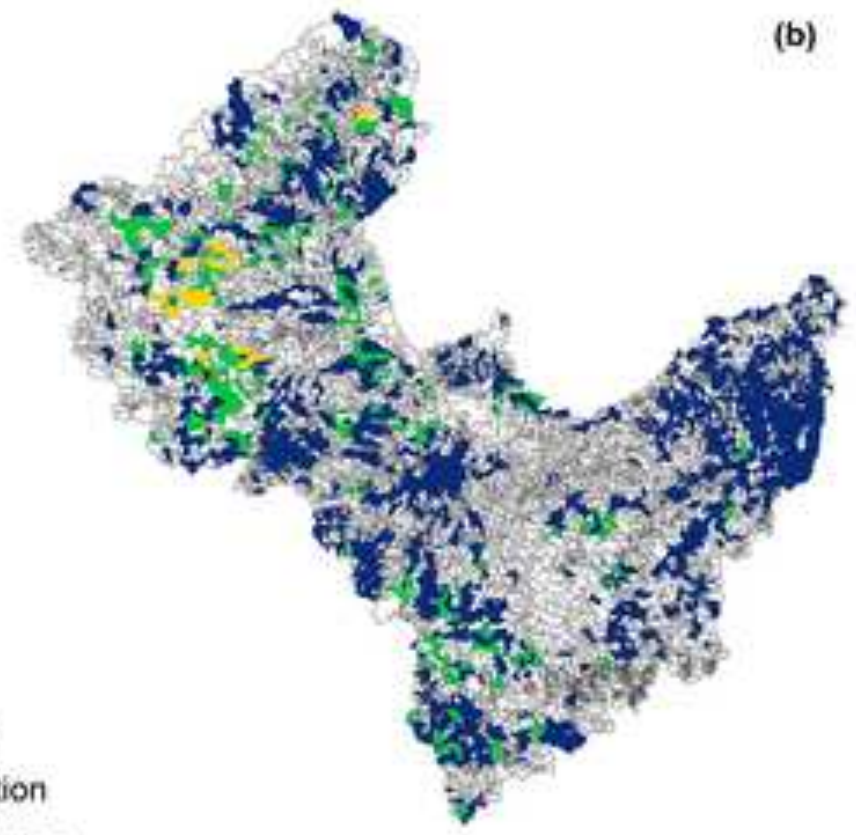

$25 \%-50 \%$ TP reduction $50 \%-75 \%$ TP reduction

$75 \%-100 \%$ TP reduction

\section{Saginaw Subbasins}

$0 \%-25 \%$ TP reduction

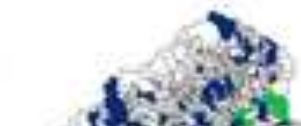

(d) (c)

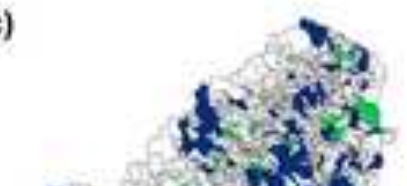

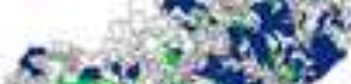

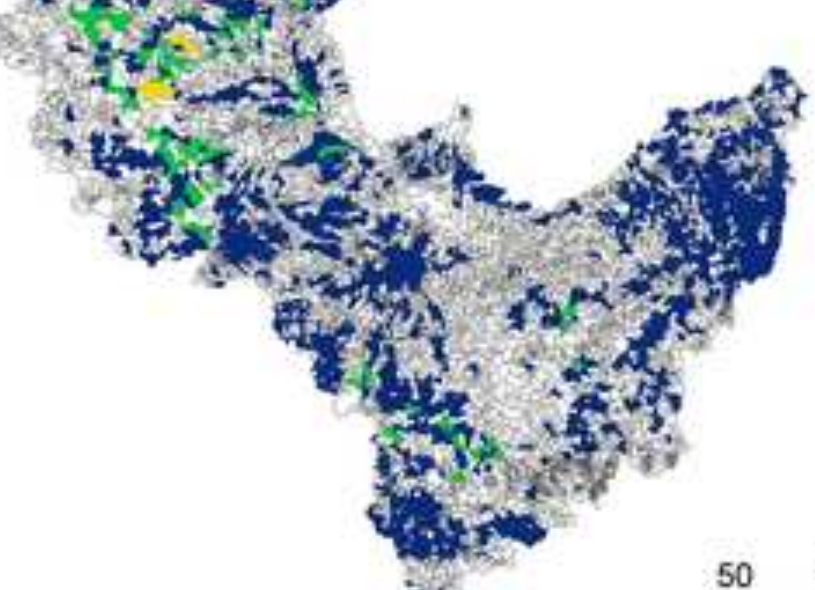

\%
50 cisen $\sin ^{2}$ Q 0 thes? 2.5.

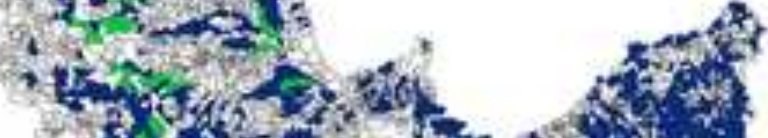


(a)

(d)

(g)
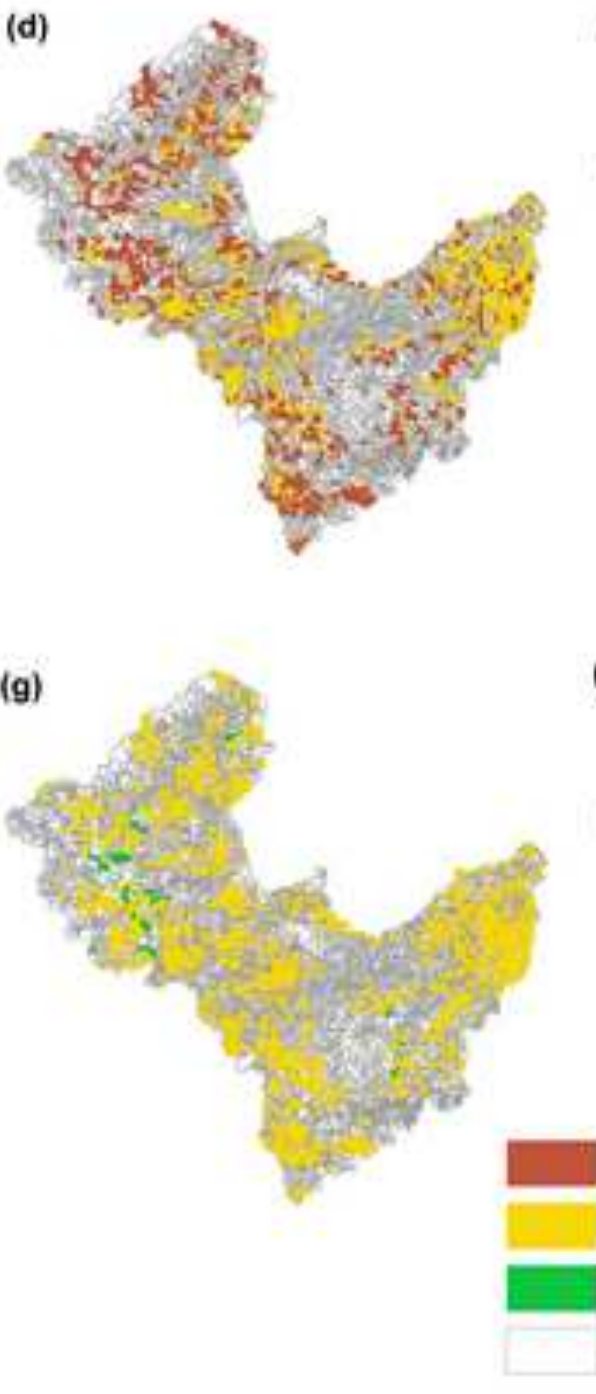

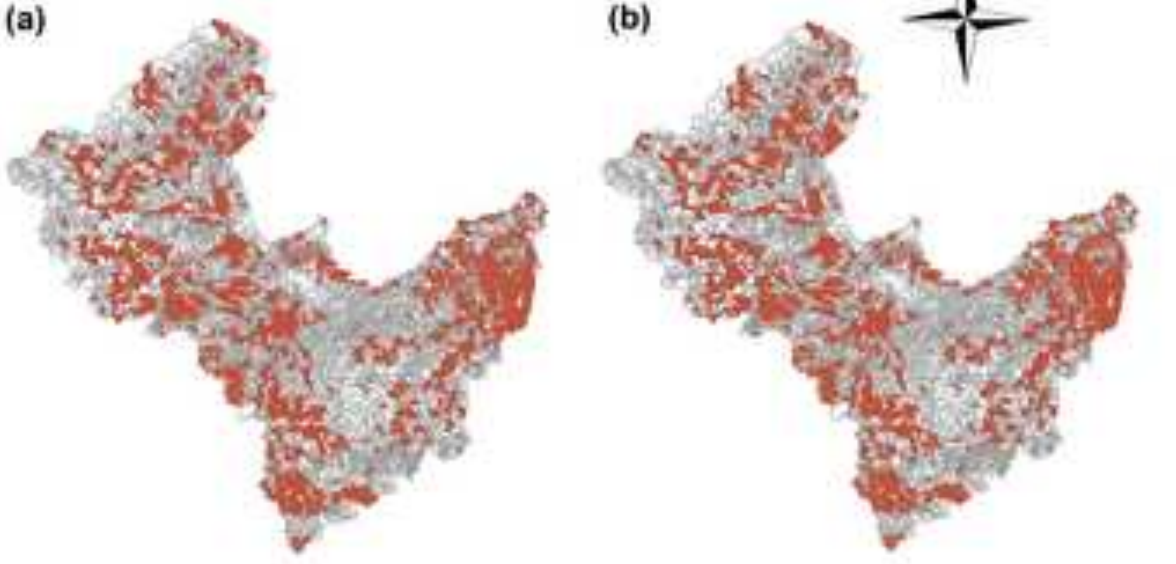

(b) $\quad t_{2}$

(e)

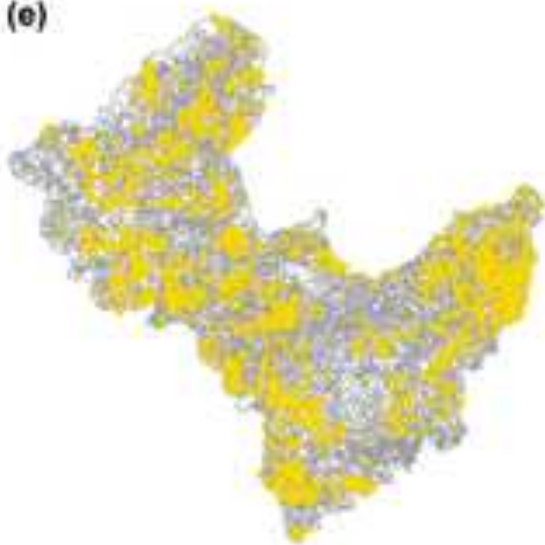

(h)

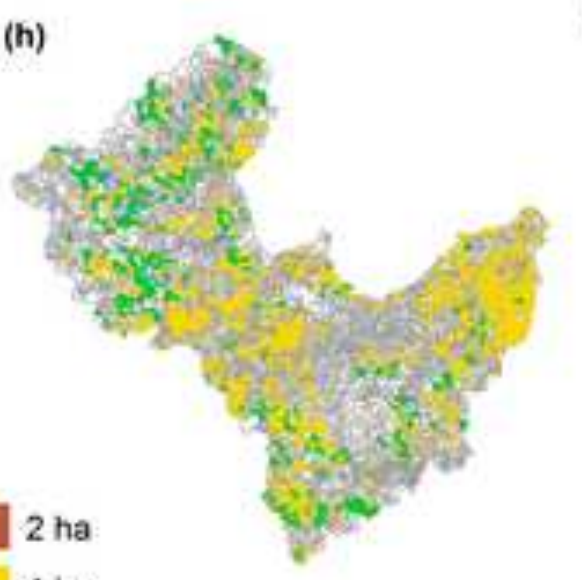

4 ha

6 ha

Subbasins (f)

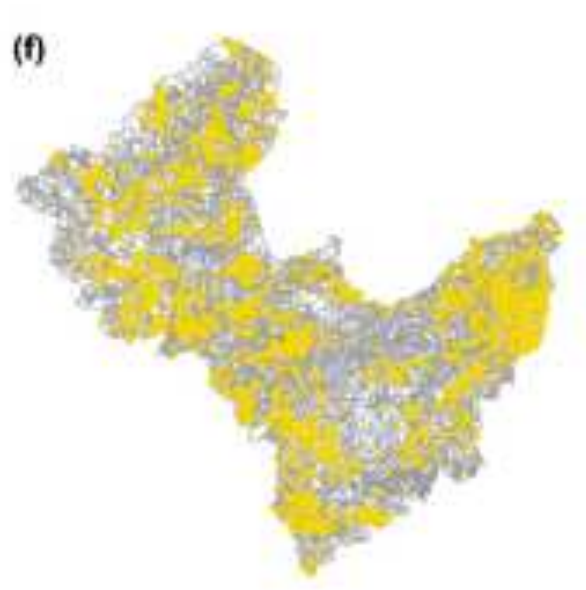

(i)

(c)
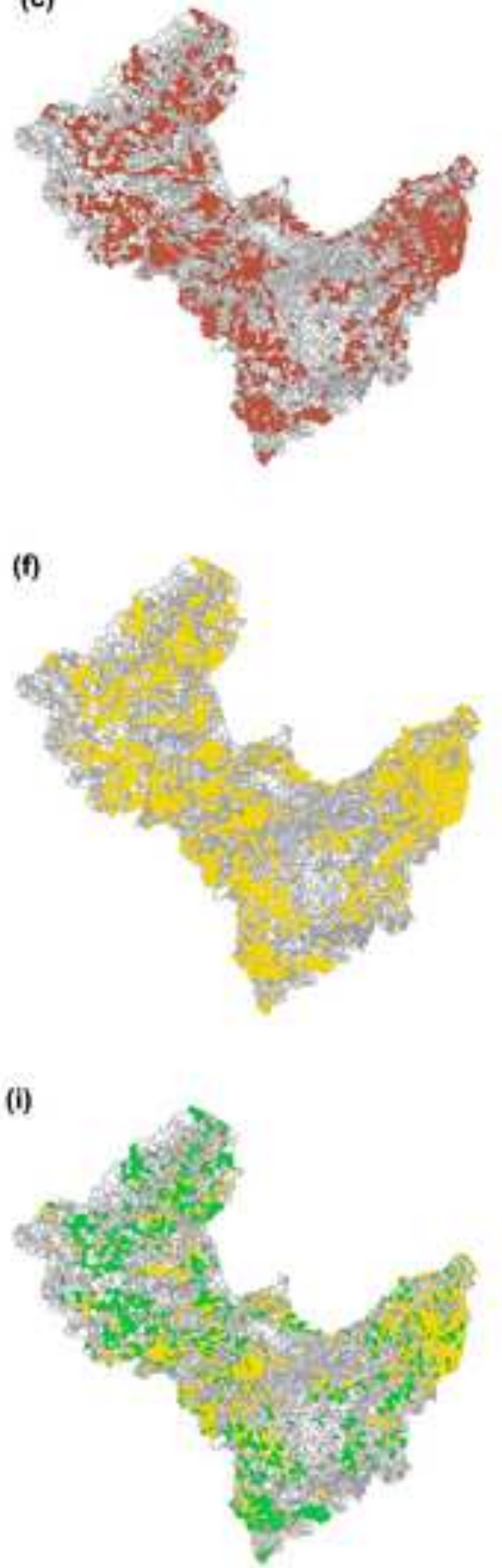

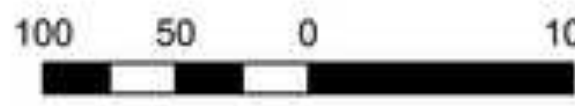
$100 \mathrm{~km}$
0

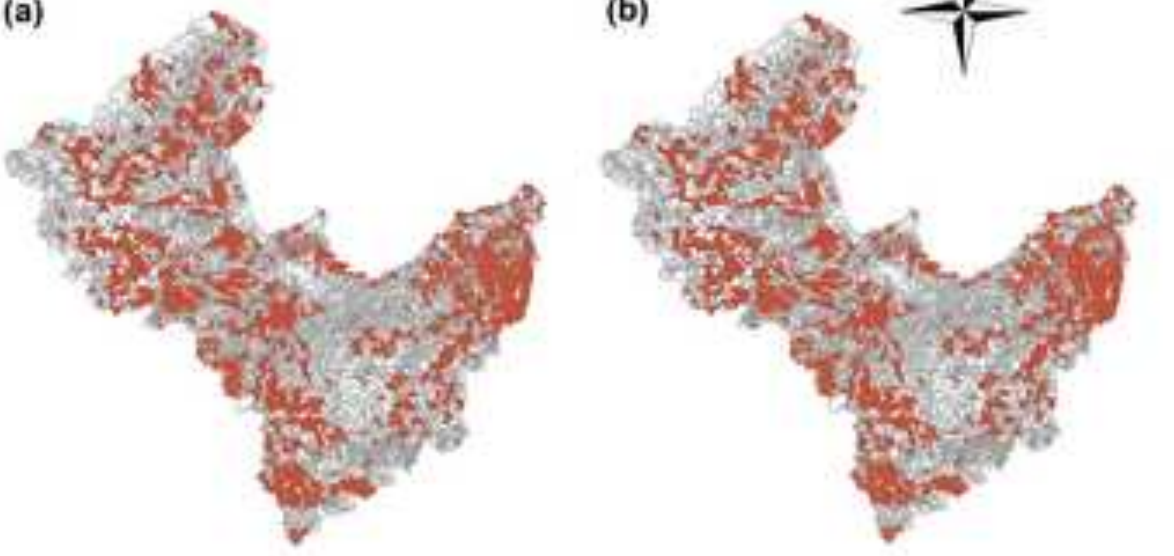

$$
\text { (n) }
$$




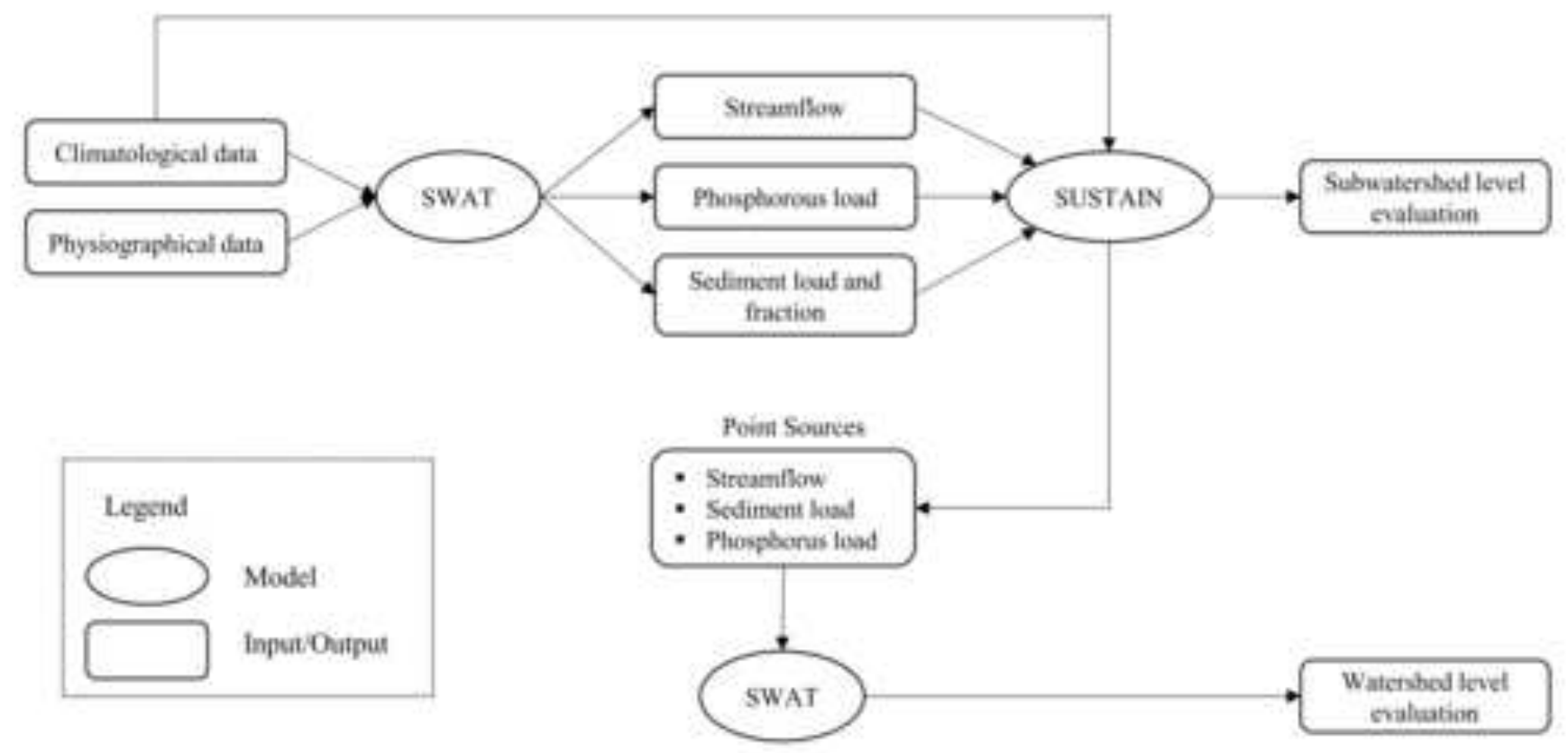




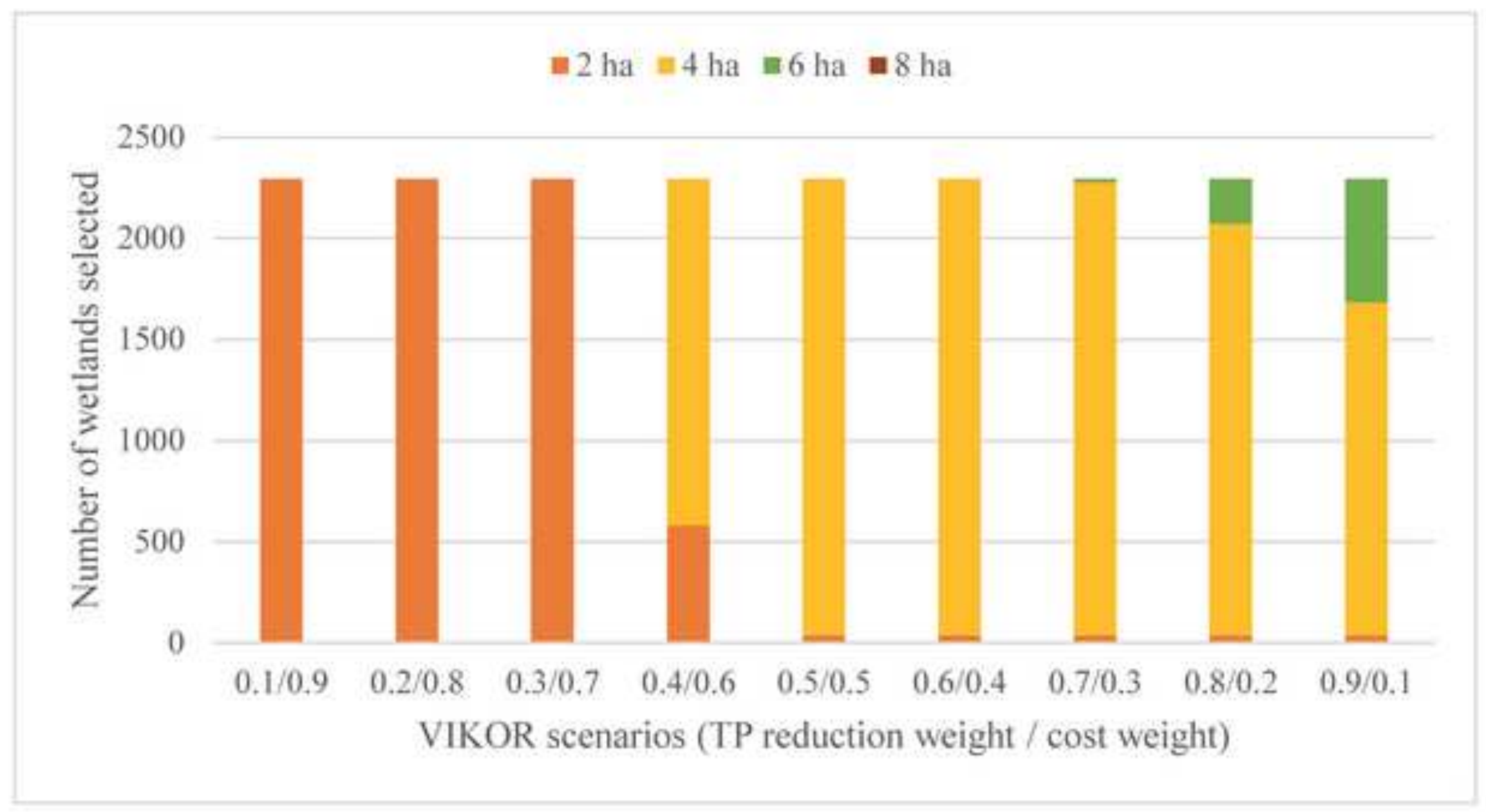


Table 1. Stream flow calibration/validation summary

\begin{tabular}{lcccccc}
\hline \multirow{2}{*}{$\begin{array}{l}\text { USGS } \\
\text { Stations }\end{array}$} & \multicolumn{3}{c}{ Calibration (2001-2004) } & \multicolumn{3}{c}{ Validation (2005-2008) } \\
\cline { 2 - 7 } & NSE & $\begin{array}{c}\text { PBIAS } \\
(\%)\end{array}$ & RSR & NSE & $\begin{array}{c}\text { PBIAS } \\
(\%)\end{array}$ & RSR \\
\hline 04144500 & 0.635 & 19.304 & 0.604 & 0.584 & 8.132 & 0.645 \\
04147500 & 0.620 & 10.244 & 0.616 & 0.614 & -9.095 & 0.621 \\
04148140 & 0.544 & 22.764 & 0.675 & 0.543 & -7.511 & 0.676 \\
04148500 & 0.669 & 24.598 & 0.575 & 0.671 & 8.181 & 0.574 \\
04151500 & 0.631 & 12.528 & 0.608 & 0.598 & 18.364 & 0.634 \\
04154000 & 0.613 & 2.484 & 0.622 & 0.576 & 11.439 & 0.651 \\
04155500 & 0.647 & 19.618 & 0.594 & 0.537 & 4.868 & 0.681 \\
04156000 & 0.773 & 0.067 & 0.476 & 0.724 & 7.963 & 0.525 \\
04157005 & 0.809 & 9.115 & 0.437 & 0.794 & 9.077 & 0.454 \\
\hline
\end{tabular}


Table 2. Sediment and total phosphorus calibration/validation summary

\begin{tabular}{ccccccc}
\hline \multirow{2}{*}{$\begin{array}{c}\text { Calibration } \\
\text { Parameter }\end{array}$} & \multicolumn{3}{c}{ Calibration (1998-2001) } & \multicolumn{3}{c}{ Validation (2002-2005) } \\
\cline { 2 - 6 } & NSE & PBIAS & RSR & NSE & PBIAS & RSR \\
$(\%)$ & \multicolumn{3}{c}{ \% $)$} & \\
\hline Sediment & 0.572 & 37.445 & 0.655 & 0.693 & 23.063 & 0.554 \\
TP & 0.609 & 27.650 & 0.625 & 0.849 & 26.828 & 0.389 \\
\hline
\end{tabular}


Table 3. Summary of average annual total phosphorus reduction

\begin{tabular}{ccc}
\hline $\begin{array}{c}\text { Wetland size } \\
\text { (ha) }\end{array}$ & $\begin{array}{c}\text { Average TP } \\
\text { reduction at } \\
\text { subwatershed level } \\
(\mathrm{kg})\end{array}$ & $\begin{array}{c}\text { Average TP } \\
\text { reduction at } \\
\text { watershed level } \\
(\mathrm{kg})\end{array}$ \\
\hline 2 & $26.92^{\mathrm{a}}$ & $25.83^{\mathrm{a}}$ \\
4 & $30.54^{\mathrm{b}}$ & $28.03^{\mathrm{b}}$ \\
6 & $32.30^{\mathrm{bc}}$ & $28.97^{\mathrm{b}}$ \\
8 & $33.33^{\mathrm{c}}$ & $29.58^{\mathrm{b}}$ \\
\hline
\end{tabular}

* TP loads with the same letter are not significantly different $(\alpha=0.05)$ 
Table 4. Stream order impact on total phosphorus reduction at subwatershed level

\begin{tabular}{cccccccccc}
\hline $\begin{array}{c}\text { Stream } \\
\text { order }\end{array}$ & $\begin{array}{c}\text { No. of } \\
\text { Subwatersheds }\end{array}$ & \multicolumn{3}{c}{$\begin{array}{c}\text { Average TP reduction (kg) for various } \\
\text { wetland sizes based on stream order }\end{array}$} \\
& & \multicolumn{3}{c}{$\begin{array}{c}\text { Average TP reduction (kg) for various } \\
\text { (horizontal comparison) }\end{array}$} & \multicolumn{3}{c}{$\begin{array}{c}\text { stream orders based on wetland sizes } \\
\text { (vertical comparison) }\end{array}$} \\
\cline { 2 - 9 } & & 2 ha & 4 ha & 6 ha & 8 ha & 2 ha & 4 ha & 6 ha & 8 ha \\
\hline 1 & 1196 & $29.49^{\mathrm{a}}$ & $33.56^{\mathrm{a}}$ & $35.59^{\mathrm{a}}$ & $36.81^{\mathrm{a}}$ & $29.49^{\mathrm{a}}$ & $33.56^{\mathrm{a}}$ & $35.59^{\mathrm{a}}$ & $36.81^{\mathrm{a}}$ \\
2 & 595 & $22.41^{\mathrm{a}}$ & $25.19^{\mathrm{ab}}$ & $26.47^{\mathrm{b}}$ & $27.19^{\mathrm{b}}$ & $22.41^{\mathrm{b}}$ & $25.19^{\mathrm{b}}$ & $26.47^{\mathrm{b}}$ & $27.19^{\mathrm{b}}$ \\
3 & 298 & $25.03^{\mathrm{a}}$ & $28.53^{\mathrm{ab}}$ & $30.21^{\mathrm{b}}$ & $31.18^{\mathrm{b}}$ & $25.03^{\mathrm{ab}}$ & $28.53^{\mathrm{bc}}$ & $30.21^{\mathrm{bc}}$ & $31.18^{\mathrm{bc}}$ \\
4 & 145 & $25.77^{\mathrm{a}}$ & $29.13^{\mathrm{a}}$ & $30.76^{\mathrm{a}}$ & $31.72^{\mathrm{a}}$ & $25.77^{\mathrm{ab}}$ & $29.13^{\mathrm{abc}}$ & $30.76^{\mathrm{abc}}$ & $31.72^{\mathrm{abc}}$ \\
5 & 48 & $33.76^{\mathrm{a}}$ & $37.77^{\mathrm{a}}$ & $39.59^{\mathrm{a}}$ & $40.61^{\mathrm{a}}$ & $33.76^{\mathrm{a}}$ & $37.77^{\mathrm{ac}}$ & $39.59^{\mathrm{ac}}$ & $40.61^{\mathrm{ac}}$ \\
$6 \& 7$ & 11 & $27.49^{\mathrm{a}}$ & $32.08^{\mathrm{a}}$ & $34.14^{\mathrm{a}}$ & $35.23^{\mathrm{a}}$ & $27.49^{\mathrm{ab}}$ & $32.08^{\mathrm{abc}}$ & $34.14^{\mathrm{abc}}$ & $35.23^{\mathrm{abc}}$ \\
\hline
\end{tabular}

* TP loads with the same letter are not significantly different $(\alpha=0.05)$ 
Table 5. Distance to outlet impact on total phosphorus reduction at subwatershed level

\begin{tabular}{|c|c|c|c|c|c|c|c|c|c|}
\hline \multirow[t]{2}{*}{$\begin{array}{l}\text { Distance to } \\
\text { outlet } \\
(\mathrm{km})\end{array}$} & \multirow[t]{2}{*}{$\begin{array}{c}\text { No. of } \\
\text { Subwatersheds }\end{array}$} & \multicolumn{4}{|c|}{$\begin{array}{l}\text { Average TP reduction (kg) for } \\
\text { various wetland sizes based on } \\
\text { distance to outlet } \\
\text { (horizontal comparison) }\end{array}$} & \multicolumn{4}{|c|}{$\begin{array}{c}\text { Average TP reduction (kg) for various } \\
\text { distances to outlet based on wetland } \\
\text { sizes } \\
\text { (vertical comparison) }\end{array}$} \\
\hline & & 2 ha & 4 ha & 6 ha & 8 ha & $2 \mathrm{ha}$ & 4 ha & 6 ha & $8 \mathrm{ha}$ \\
\hline $0-50$ & 164 & $12.13^{\mathrm{a}}$ & $13.94^{\mathrm{a}}$ & $14.72^{\mathrm{a}}$ & $15.13^{\mathrm{a}}$ & $12.13^{\mathrm{a}}$ & $13.94^{\mathrm{a}}$ & $14.72^{\mathrm{a}}$ & $15.13^{\mathrm{a}}$ \\
\hline $50-100$ & 516 & $25.25^{\mathrm{a}}$ & $28.77^{\mathrm{b}}$ & $30.24^{\mathrm{b}}$ & $31.00^{\mathrm{b}}$ & $25.25^{\mathrm{b}}$ & $28.77^{\mathrm{b}}$ & $30.24^{\mathrm{b}}$ & $31.00^{\mathrm{b}}$ \\
\hline $100-150$ & 696 & $28.93^{\mathrm{a}}$ & $33.32^{\mathrm{b}}$ & $35.57^{b}$ & $36.93^{\mathrm{b}}$ & $28.93^{\mathrm{c}}$ & $33.32^{\mathrm{c}}$ & $35.57^{\mathrm{c}}$ & $36.93^{c}$ \\
\hline $150-200$ & 778 & $27.16^{\mathrm{a}}$ & $30.50^{\mathrm{ab}}$ & $32.18^{\mathrm{b}}$ & $33.21^{\mathrm{b}}$ & $27.16^{\mathrm{bc}}$ & $30.50^{\mathrm{bc}}$ & $32.18^{\mathrm{bc}}$ & $33.21^{\mathrm{bc}}$ \\
\hline $200-250$ & 139 & $39.11^{\mathrm{a}}$ & $42.94^{\mathrm{a}}$ & $44.91^{\mathrm{a}}$ & $46.12^{\mathrm{a}}$ & $39.11^{\mathrm{d}}$ & $42.94^{\mathrm{d}}$ & $44.91^{\mathrm{d}}$ & $46.12^{\mathrm{d}}$ \\
\hline
\end{tabular}

* TP loads with the same letter are not significantly different $(\alpha=0.05)$ 